\title{
Susceptibility of earth-based construction materials to fungal proliferation: laboratory and in situ assessment
}

\author{
Alexis Simons ${ }^{a, b} * *$, Alexandra Bertron ${ }^{b}$, Christophe Roux ${ }^{c}$, Aurelie Laborel-Préneron ${ }^{b}$, Jean-Emmanuel \\ Aubert ${ }^{b}$, Christine Roques ${ }^{a}$ \\ a Laboratoire de Génie Chimique, Université de Toulouse, UMR 5503 CNRS - UPS - INPT, Toulouse, France \\ b Laboratoire Matériaux et Durabilité des Constructions, Université de Toulouse, UPS, INSA, Toulouse, France \\ c Laboratoire de Recherche en Sciences Végétales, Université de Toulouse, UPS, CNRS 24 Chemin de Borde Rouge-Auzeville, Castanet-Tolosan, \\ France
}

Received: 19 October 2018 / Accepted: 10 April 2019 / Published online: 18 April 2019

(C) The Author(s) 2019. This article is published with open access and licensed under a Creative Commons Attribution 4.0 International License.

- The first author was invited for publication of this letter as a winner of the $2^{\text {nd }}$ prize in the Young Researcher Competition organized in the framework of the RILEM 253-MCI Conference (Toulouse, France, 25-26 June 2018).

\begin{abstract}
The impact of building materials on the environment and the health of occupants has become a priority issue. Ecological construction materials, such as earthen materials, are currently experiencing a regain of interest for both ecological and economic reasons. However, since microbial proliferation on indoor materials can induce a deterioration of the air quality in the building and lead to an increase in health risks for the occupants, the issue of indoor air quality raises questions about the utilization of earthen building materials and their possible susceptibility to fungal development. The microflora of earthen materials and its ability to grow on such supports have been little studied so far. This study focuses on the quantification of both bacterial and fungal microflora throughout the manufacturing process and the impact of extreme humidity, simulating a hydric accident, on microflora development analyzed on the surface of and inside earthen bricks. The initial microflora of these materials was dramatically reduced during the manufacturing process, especially after heat treatment for drying. The remaining microorganisms were observed to proliferate only under conditions of high humidity, in particular for earthen materials with vegetal aggregates. Moreover, in situ samplings were performed on naturally dried earthen materials used in buildings. The characterization of their microbial density revealed that it was higher than on manufactured specimens, while microbial concentration and detected taxa seemed mainly related to the room use and building history. These results provide a better understanding of microbial proliferation on these materials.
\end{abstract}

Keywords: Earthen bio-based building materials; Fungal proliferation; In situ sampling

\section{Introduction}

Current ecological concerns are leading us to give greater consideration to the environmental impact of building materials. Earthen materials are part of the several environmentally friendly materials used to address these ecological challenges. Earthen building materials have a variety of interesting characteristics, such as their capacity to induce natural regulation of the indoor air humidity [1], their reduced environmental impact [2] and their low cost [3]. The addition of vegetal aggregates (straw, hemp, etc.) within earthen materials induces an improvement in their thermal insulation as well as a reduction of shrinkage cracks when the materials dry out after manufacturing [4]. The addition of compounds containing cellulose and/or lignin may, however, promote microbial growth [5]. Microbial proliferation in buildings has become a major challenge in recent decades because of its involvement in the degradation of indoor air quality. Nowadays, humans spend more than $80 \%$ of their time inside buildings [6], which leads to high exposure to indoor air [7]. The percentage of buildings contaminated by indoor molds is estimated at 20 to $40 \%$ for Northern Europe and North America [8]. During their growth, microorganisms release several gases and harmful particles (VOCs, parietal compounds, toxins, spores, etc.) into the indoor environment, thus inducing various health risks for the inhabitants, such as the development of asthma, allergies, ocular and pulmonary irritations or infections [8] or more global issues such as Sick Building Syndrome [9].

There is an urgent need to characterize the conditions of microbial growth on building materials. Several factors are involved, and one of the most important corresponds to the environmental conditions. Humidity is a key factor for the 
development of bacteria and fungi on construction materials $[10,11]$ and high, uncontrolled relative humidity (i.e. RH between $70 \%$ and $90 \%$ ) inside buildings leads to microbial proliferation [12]. The minimal relative humidity needed for fungal growth, however, depends on the composition of the building material [12,13]: i) $70 \% \mathrm{RH}$ for wood-based materials, ii) $85 \%$ RH for plaster and iii) $90 \%$ to $95 \% \mathrm{RH}$ for cementitious materials and concretes. Moreover, some differences in fungal susceptibility can be observed between similar materials under the same environmental conditions [14]. In addition, the type of material has a significant impact on the type of microorganisms able to grow and on their growth kinetics $[11,15,16]$. Concerning earthen building materials, fungal proliferation issues have only been reported for specific environmental conditions, such as water-related accidents or a building being poorly ventilated during the drying of the materials after casting $[17,18]$. These occurrences may raise questions about the conditions of microbial proliferation on these materials and their use for construction. However, very few studies have characterized the susceptibility of earthen materials and there is a real need to clarify this aspect.

It is also necessary to assess the presence of microorganisms on the surface of construction materials inside buildings in order to better evaluate the risks of proliferation on these materials. Several studies have characterized the microbial flora of conventional buildings, by culture-based methods [19-21] or using molecular analyses [22-25]. The major impact of the human microbiome on the indoor bacterial flora has been highlighted [26], as has the predominance of outdoor fungi in the indoor air and on surfaces $[22,27]$. The characterization of microbial diversity at the surface of earthen materials in situ has recently revealed that fungal flora are related to the outdoor and indoor environment, but the main bacterial flora is not associated with that of the occupants [28]. The major factors impacting microbial flora composition are the history of the buildings and the way materials are used (indoors / outdoors). Experimental characterizations of earthen materials carried out in the laboratory need to be put in perspective though in situ assessments on earthen buildings than may have been exposed to different uses and environmental conditions over time.

This study aimed to improve the knowledge of microorganisms present in manufactured and in situ earthen materials and their abilities to proliferate on these materials. With this in mind, the aims of the research work were to i) quantify the initial microflora in manufactured earthen materials, regarding their composition (addition of vegetal aggregates or not) and the manufacturing process, ii) evaluate the proliferation of microorganisms remaining on earthen materials, under both conventional and very high humidity conditions, and iii) evaluate the microbial density and taxa of both bacteria and fungi on the surface of in situ earthen materials, using culture-based approaches.

\section{Materials and methods}

\subsection{Manufactured materials}

Quarry Fines from Aggregate Washing (FWAS) were used as the earth material for this study. These materials are waste from the washing step of the limestone quarrying process and the sludges obtained are deposited in sedimentation basins until they dry. Then, they are transformed into powder to obtain the final product. The FWAS used here consisted of calcite $(60 \%)$, kaolinite $(11 \%)$, illite $(11 \%)$, quartz $(10 \%)$, dolomite (6\%) and goethite (3\%) [29]. The material $\mathrm{pH}$ was 7.8. The FWAS was composed of extremely fine particles, with $99 \%$ smaller than $80 \mu \mathrm{m}$. The mean size determined by pipette was around $6.5 \mu \mathrm{m}$. Barley straw was used for the addition of plant fibers into the raw earth material. The length of the barley straw strands was between 10 and $30 \mathrm{~mm}$. The FWAS and barley straw were stored at ambient temperature and lighting in plastic bags until their use in the manufacturing of earthen materials.

Two formulations were manufactured: i) specimens composed of earth materials only (FWAS-SO\%) and ii) specimens composed of FWAS with $3 \%$ of straw by weight (FWAS-S3\%). The earth and straw parts were first mixed by hand. Then, water was added and the materials were mixed mechanically until a homogeneous mixture was obtained. Specimens were manufactured by double static compression at the Proctor density into cylindrical molds $5 \mathrm{~cm}$ in diameter and $5 \mathrm{~cm}$ high (Fig. 1). Manufactured specimens were first dried at $40{ }^{\circ} \mathrm{C}$ for 24 hours, then the temperature was increased by $0.1{ }^{\circ} \mathrm{C} / \mathrm{min}$ until it reached $100{ }^{\circ} \mathrm{C}$. The temperature was maintained at $100{ }^{\circ} \mathrm{C}$ until the mass was constant (mass variation less than $0.1 \%$ between two weighings $24 \mathrm{~h}$ apart). This drying step was performed in order to accelerate the fabrication process with respect to natural drying. Similar drying processes are used in brickyards before firing. The specimens were then transferred from the manufacturing room to the microbiology laboratory and stored, sterile conditions and room temperature being maintained during the transfer and storage. The density of the dry specimens was $1.99 \mathrm{~g} . \mathrm{cm}^{-3}$ for the FWAS-SO\% composition and $1.52 \mathrm{~g} . \mathrm{cm}^{-3}$ for the FWAS-S3\% composition. Some additional data on the manufacture and the characterization of the bricks are available in $[30,31]$.

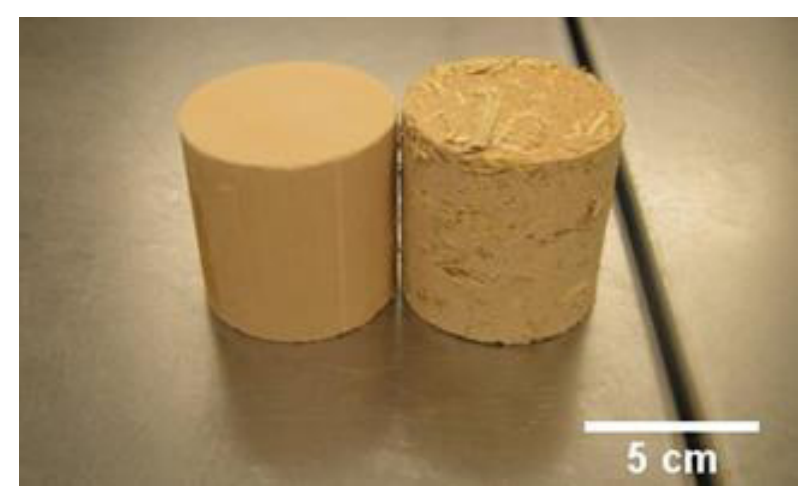

Figure 1. Manufactured specimens of FWAS-SO\% (left) and FWAS-S3\% (right). 


\subsection{Evaluation of the initial microflora on earthen materials during the manufacturing process}

In order to determine the initial microflora present, samples of the manufactured specimens were taken: i) on the surface of the specimens, before and after the drying step, and ii) inside the specimens, after the drying step and horizontal breaking of specimens using a splitting test with $100 \mathrm{kN}$ hydraulic press. Two specimens were used per composition (FWAS-SO\% and FWAS-S3\%). Sampling was carried out with 4 $\mathrm{cm}^{2}$ sterile adhesives (Hydrofilm ${ }^{\circledast}$ - Hartmann) pressed manually onto the defined area for 5 minutes. Adhesives were then transferred into $10 \mathrm{~mL}$ of recovery medium (Phosphate Buffered Saline (PBS) $+5 \% \mathrm{w} / \mathrm{w}$ final concentration of Tween 80 ). The solution was vortexed for 5 minutes to remove adhered microorganisms from the adhesives [32]. For cell numeration (CFU: Colony Forming Units), one tenth dilutions were performed and $100 \mu \mathrm{L}$ of each dilution was deposited on different nutritive media: i) Tryptone Soy Agar (TSA), incubated for 2 days at $32.5^{\circ} \mathrm{C}$ for bacterial numeration; and ii) Potato Dextrose Agar (PDA) supplemented with $0.05 \mathrm{mg} / \mathrm{mL}$ of chloramphenicol $(\mathrm{Cm})$ and incubated for 5 days at $22{ }^{\circ} \mathrm{C}$ for fungal numeration. The adhesives used for sampling the inside part of the specimens were directly deposited on PDA-Cm medium and incubated for 7 days at $22.5^{\circ} \mathrm{C}$ in order to observe fungal development.

\subsection{Simulation of high humidity conditions for earthen materials}

Earthen materials are very sensitive to liquid water as well as condensed vapor due to high humidity conditions with poor ventilation [33]. A method of humidification by capillarity was set up in order to avoid the dispersion of the earthen material in direct contact with water [34]. The following system was used under controlled conditions (in microbial safety cabinets, at room temperature) (Fig.2): a sterile clay brick covered by a piece of sponge was placed in a sterile basin; three dried specimens of the same composition were placed on the sponge; the basin was filled with sterile water which was maintained at almost the height of the clay brick, leading to a humidification of the specimens by capillarity without disintegration. One basin was set up for each of the compositions (FWAS-SO\% and FWAS-S3\%). Two control specimens of each composition were placed under controlled conditions without being humidified. The specimens were placed at room temperature for both conditions (humid and control) and room humidity for control condition. The specimens were regularly observed during 3 months.

At the end of the 3 months of observation, two specimens of each condition (composition / humidity) were broken horizontally using a $100 \mathrm{kN}$ hydraulic press. Microbial sampling was performed using adhesive tape for both the surface and the inside of the broken specimens (see subsection 2.2). CFU were counted as previously described for surface samples (see subsection 2.2).

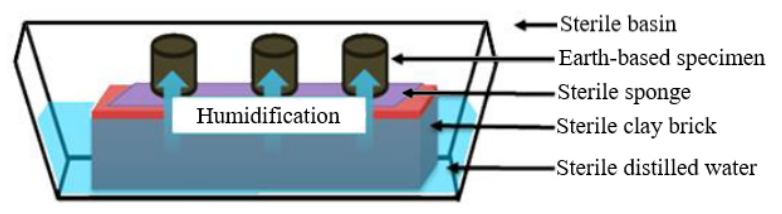

Figure 2. Diagram of the capillarity humidification system.

\subsection{Evaluation of the microbial flora on earthen building materials in situ}

This campaign was carried out on a total of 5 buildings with earthen walls located in south-west France (Table 1 \& Fig. 3). The sampling campaign was carried out between October and November 2015. The different sampled surfaces, referenced $\mathrm{A}, \mathrm{Ba}, \mathrm{Bb}, \mathrm{C}$ and $\mathrm{D}$, were selected for their different current functions (hall, kitchen, office, cellar). The building material sampled was composed of raw earth only $(A, B a, D)$ or raw earth with plant fibers $(B b, C)$. The history of the building was also considered. Four sampled sites (A, Bb, C and $D$ ) were in normal moisture conditions during sampling (i.e. no visible microbial proliferation due to hydric accident) and the fifth one (Ba), which had shown signs of mold proliferation less than one year before sampling, had returned to a dry state without visible mold a few months previously. Samples were collected by scratching the surface of earthen materials with sterile scalpels. Three to six small areas $\left(4 \mathrm{~cm}^{2}\right)$ located at different heights (i.e. $40 \mathrm{~cm}$ to $190 \mathrm{~cm}$ from the floor) were sampled per site, 2 to $3 \mathrm{~g}$ of material being collected from each area.

Table 1. Information about in situ sampling

\begin{tabular}{|c|c|c|c|c|c|c|c|}
\hline $\begin{array}{l}\text { Sampling } \\
\text { label }\end{array}$ & $\begin{array}{l}\text { Number of } \\
\text { samples }\end{array}$ & Type of material & Function & $\begin{array}{l}\text { Date of } \\
\text { building }\end{array}$ & History & Location & $\begin{array}{l}\text { Sampling } \\
\text { month }\end{array}$ \\
\hline A & 6 & Raw earth adobe & Hall & $\begin{array}{l}\text { Before } \\
1800\end{array}$ & $\begin{array}{l}\text { Previously a barn housing farm } \\
\text { animals }\end{array}$ & Maureville & $\begin{array}{c}\text { September } \\
2015\end{array}$ \\
\hline $\mathrm{Ba}$ & 4 & Raw earth adobe & Hall & $\begin{array}{c}\text { August } \\
1995\end{array}$ & $\begin{array}{c}\text { Previous fungal development } \\
\text { caused by a blocked drain }\end{array}$ & $\begin{array}{l}\text { Castanet- } \\
\text { Tolosan }\end{array}$ & October 2015 \\
\hline $\mathrm{D}$ & 3 & Raw earth adobe & Kitchen & Unknown & $\begin{array}{c}\text { Probable presence of a plaster } \\
\text { on the surface of the wall }\end{array}$ & Maureville & $\begin{array}{l}\text { November } \\
2015\end{array}$ \\
\hline C & 4 & $\begin{array}{l}\text { Plaster (raw earth } \\
+ \text { hemp) }\end{array}$ & Office & $\begin{array}{l}\text { Spring } \\
2009\end{array}$ & Dwelling & Lanta & $\begin{array}{l}\text { November } \\
2015\end{array}$ \\
\hline $\mathrm{Bb}$ & 5 & $\begin{array}{c}\text { Cob (raw earth }+ \\
\text { straw) }\end{array}$ & Cellar & $\begin{array}{l}\text { August } \\
1995\end{array}$ & $\begin{array}{c}\text { Regular storage of fruit and } \\
\text { vegetables }\end{array}$ & $\begin{array}{l}\text { Castanet- } \\
\text { Tolosan }\end{array}$ & October 2015 \\
\hline
\end{tabular}




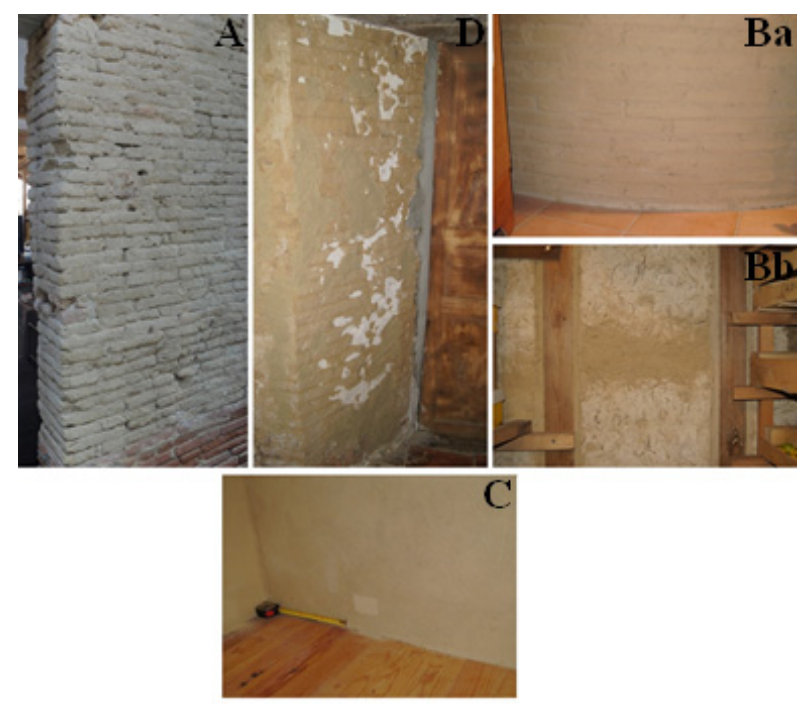

Figure 3. Earthen building sampling sites.

The materials sampled in situ were used for microbial isolation on culture media. One gram of sampled materials was mixed with $10 \mathrm{~mL}$ of recovery medium (PBS $+5 \%$ Tween 80 ) and shaken at $300 \mathrm{rpm}$ for $30 \mathrm{~min}$ [32]. Suspensions were diluted, deposited on the culture media and incubated at different temperatures as previously described in subsection 2.2. Concerning fungal isolation, a DG18 medium supplemented with $0.05 \mathrm{mg} / \mathrm{mL}$ of $\mathrm{Cm}$ was used in addition to PDA, in order to isolate any xerophilic fungi present.

\subsection{Microbial identification}

Microbial isolates obtained on both of the manufactured specimens were characterized. Fungi were identified by macro- and microscopic observations. Fungal microscopic characterization was performed by cotton blue staining and observation by optical microscopy $(\times 400)$. Bacteria were identified using MALDI-TOF mass spectrometry. Bacterial colonies were sampled and homogeneously deposited on MALDI target positions (MSP 96 polished steel BC target). One microliter of $70 \%$ formic acid was then deposited on each MALDI target position and left to dry. One microliter of IVD
Matrix HCCA matrix (Bruker, Billerica - Massachusetts, U.S.A.) was reconstituted with $250 \mu \mathrm{L}$ organic solvent solution (acetonitrile 50\%, water 47.5\%, TFA 2.5\%) (Sigma-Aldrich, Saint-Louis - Missouri, U.S.A.) and $1 \mu \mathrm{L}$ of this matrix was deposited on each position. One internal control BTS (Bacterial Test Standard) was also deposited on each MALDI target. The MALDI target was then analyzed after the drying of all positions. A MALDI-TOF BioTyper (Bruker, Billerica Massachusetts, U.S.A.) analyzed the protein profile of each isolate. The IVD MALDI BioTyper database version 4.0(5627) was used to compare reference and acquired spectra. The threshold score for spectrum congruence and the proposed list were examined for the acceptance of identification results.

\subsection{Statistical analysis}

The means and standard deviations were calculated in each condition on the log10 values. A Student test was carried out to compare the means between them. The computations were performed using the R software. A p-value below 0.05 is indicated by an asterisk above the relevant averages in Fig.4, 7 and 8 .

\section{Results}

\subsection{Evaluation of the initial microflora on earthen materials during the manufacturing process}

Samples were taken during the manufacturing process in order to assess the initial presence of microorganisms in the manufactured earthen materials studied. Numerations of cultivable microorganisms (expressed in CFU per $\mathrm{cm}^{2}$ of adhesive) sampled on the surface of the FWAS-SO\% and FWAS-S3\% specimens are reported in Fig. 4. These samples were taken before (Fig. 4.A) and after (Fig. 4.B) the drying step. The undried FWAS-S3\% specimens contained around 1 $\log 10$ more bacteria and fungi per $\mathrm{cm}^{2}$ than the undried FWAS-SO\% specimens. The addition of plant fibers led to the detection of a greater number of microorganisms than found on the surface of the earth-only specimens, even with only $3 \%$ of straw.

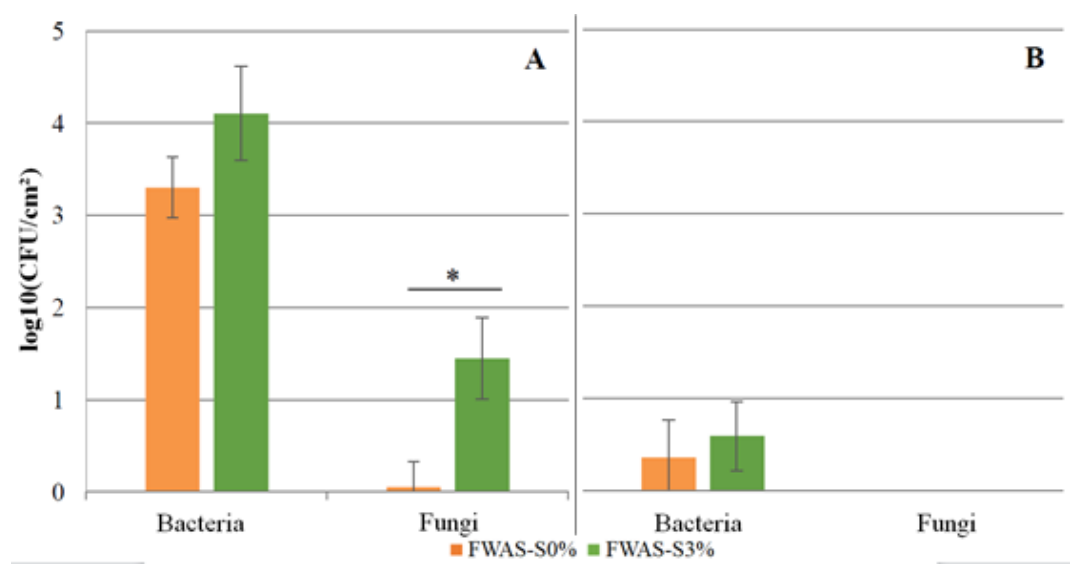

Figure 4. Colony Forming Units (average \pm standard deviation; three independent assays in triplicate) per $\mathrm{cm}^{2}$ of adhesive obtained by sampling the surface of undried specimens (A) or specimens dried at $100^{\circ} \mathrm{C}(\mathrm{B})$. 
Samples from dried FWAS-SO\% specimens contained 3 bacterial CFU per $\mathrm{cm}^{2}$ of adhesive on average, whereas the quantity was $2.6 \pm 2.3 \times 10^{3} \mathrm{CFU} / \mathrm{cm}^{2}$ before the drying step. Similarly, samples from dried FWAS-S3\% specimens contained less than $10 \mathrm{CFU} / \mathrm{cm}^{2}$, while undried specimens initially presented $2.7 \pm 2.2 \times 10^{4} \mathrm{CFU} / \mathrm{cm}^{2}$ on their surface. Concerning fungal numeration, less than $1 \mathrm{CFU} / \mathrm{cm}^{2}$ was obtained for both compositions.

The amount of fungi counted inside dried specimens was below the limit of CFU quantification with the method used. In order to better explore the fungal flora on and inside the dried specimens by qualitative approaches, samples were collected on the surface and inside the dried specimens and the adhesives were then directly deposited on the culture media (Fig. 5), for both FWAS-S0\% (Fig. 5.A) and FWAS-S3\% (Fig. 5.B). Very few molds were observed on surface samples (less than one isolate per sample) and only for the FWAS-S3\% composition. However, various molds were isolated from the inside part of the samples, suggesting the survival of some of the microorganisms initially present in the manufactured material, even after the drying step.

\subsection{Simulation of high humidity condition for earth-based materials}

As the microbial flora contained in the manufactured materials was not totally removed by the fabrication process, a simulation of high humidity conditions was performed to determine whether the remaining microorganisms were able to grow in the material. Dried specimens were observed for three months in: (i) dry condition; and (ii) humid condition, i.e. a total humidification achieved by water ascent in the building material. No visible development of fungi was observed on the specimens placed in the dry condition (Fig. 6). Some white mycelia appeared on the specimens of both compositions after one month the in humid condition, and grew slowly. Few fungi had developed on the FWAS-SO\% specimens after 6 weeks in the humid condition (Fig. 6.A). At the same observation time, two FWAS-S3\% specimens presented considerable development of black mold on their surface (Fig. 6.B). These fungal developments on dried specimens placed in the humid condition confirmed the previous observations about the persistence of microorganisms. After 2 months, additional different molds had developed on the surface of specimens, with some heterogeneity in terms of location and macroscopic properties. These results suggest that not all microorganisms had the same revival and growth kinetics in the material, although some of them survived the heat treatment inside the specimens.

After 3 months, samples were taken in order to quantify the proliferation on the surface and inside the specimens. Fig. 7 presents the bacterial (Fig. 7.A) and fungal (Fig. 7.B) numerations for each sample for each moisture condition and sampling location. No significant difference was observed between the surface and the inside for specimens placed in dry conditions, regardless of their composition. However, the bacterial quantification after 3 months detected between $8.5 \times 10^{1}$ to $4.1 \times 10^{2} \mathrm{CFU} / \mathrm{cm}^{2}$ whereas $10^{1} \mathrm{CFU} / \mathrm{cm}^{2}$ were found just after the drying step. Similarly, fungi could be detected after 3 months, which was not the case just after the manufacturing process. Microorganisms were thus able to grow in the building material despite the "dry" condition (ambient relative humidity), but remained at low concentrations.

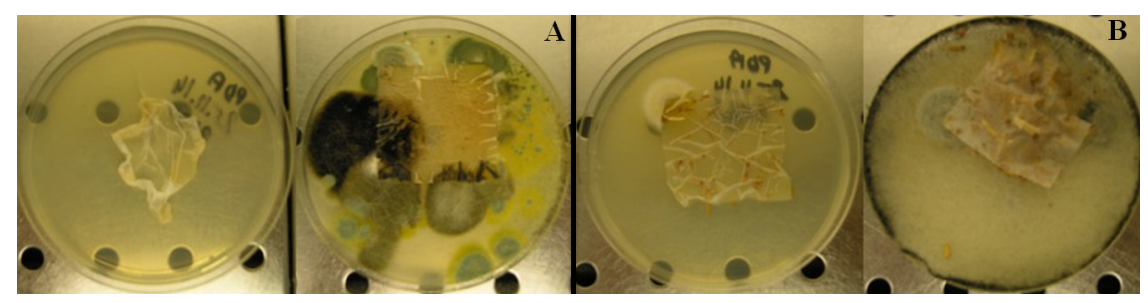

Figure 5. Isolates obtained after 7 days at $22.5^{\circ} \mathrm{C}$ from samples taken on FWAS-SO\% (A) and FWAS-S3\% (B) specimens. Sampling was performed on the surface of (on the left) and inside (on the right) each specimen.

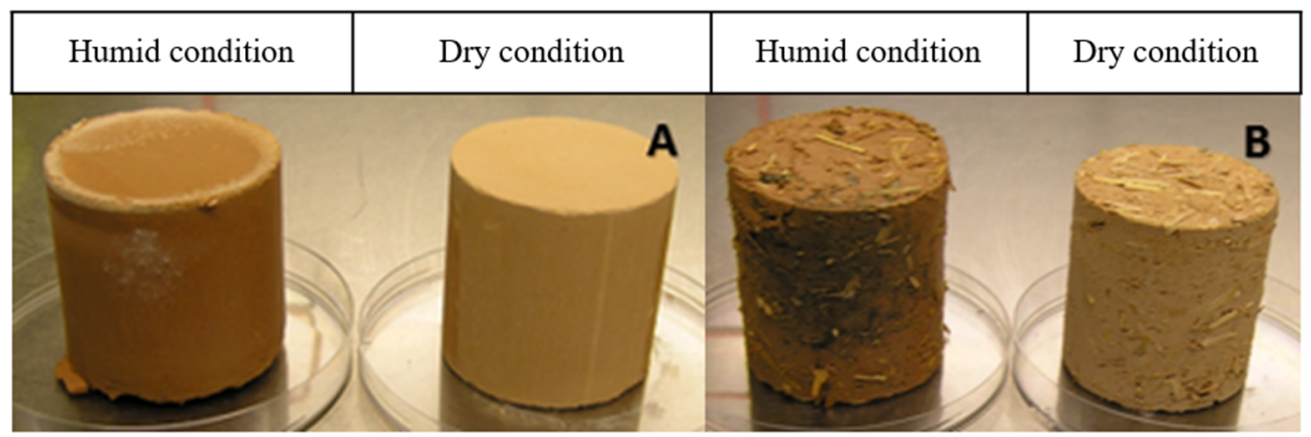

Figure 6. FWAS-SO\% (A) and FWAS-S3\% (B) specimens observations after an incubation at room temperature under humid condition (specimen on the left) or dry condition (specimen on the right). 
Very significant bacterial growth was observed for both compositions and sampling locations when the specimens were placed in the humid condition. The humid FWAS-S0\% specimens did not show significantly more fungi on their surface than those in the dry condition, except in one area where mycelium was visible, which suggested a very localized mold development or a very long latency phase. However, a significant increase of the fungal development was detected inside humid specimens in comparison with dry specimens despite 72 hours' drying at $100{ }^{\circ} \mathrm{C}$, validating the second hypothesis. Concerning the FWAS-S3\% composition, samplings on specimens under the humid condition revealed considerable fungal growth at both sampling locations, including surfaces without visible mycelium. Moreover, FWAS-S3\% specimens under the high humidity condition presented a larger quantity of microorganisms than FWASSO\% in the same condition. Thus, the presence of straw could have an impact by maintaining microorganisms and promoting their secondary development and/or by increasing the porosity and therefore the humidity in the material. were isolated and counted (Fig. 8). Bacteria densities varied according to the sampling site, with a higher concentration for samples from building $\mathrm{Bb}\left(1.9 \times 10^{6} \mathrm{CFU} / \mathrm{g}\right)$, and a lower concentration for site $D\left(2.7 \times 10^{4} \mathrm{CFU} / \mathrm{g}\right)$. In the case of site $A$, the quantity of cultivable bacteria varied greatly depending on the height at which the sample was taken. While samples collected at $120 \mathrm{~cm}$ and $100 \mathrm{~cm}$ showed high bacterial colonization (i.e. around $10^{7} \mathrm{CFU} / \mathrm{g}$ ), the rest of the wall showed significantly lower quantities, in the range $10^{4}$ to $10^{5}$ CFU/g. No significant difference was observed between isolates identified across the various heights sampled for this support. This intra-site variation confirms the need to collect wall samples at different locations when possible, in order to ensure that they are representative of the entire support.

Concerning fungal numeration, the two sites $\mathrm{Ba}$ and $\mathrm{Bb}$ presented the highest quantity of molds (more than $10^{3}$ CFU/g) while the fungal concentration at all other sites was below $10^{2} \mathrm{CFU} / \mathrm{g}$. The use of DG18 medium led to the isolation of a high concentration of Wallemia sp. from the Ba support.

\subsection{Characterization of microorganisms on earthen materials in situ}

In situ sampling was performed in five different earthen buildings and the microorganisms contained in the samples

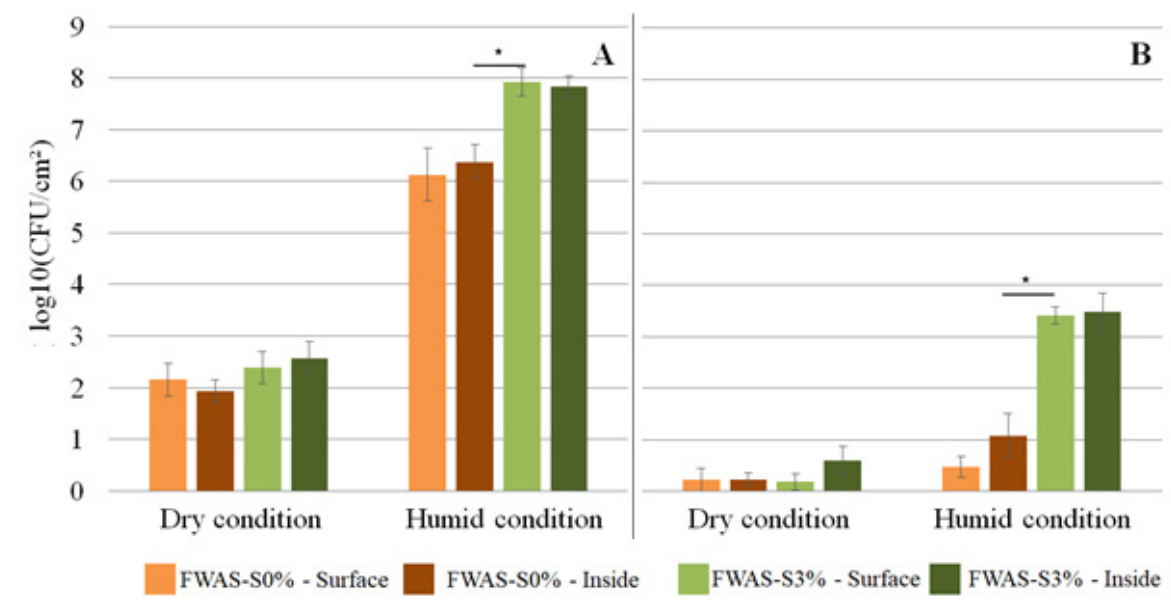

Figure 7. Bacterial (A) and fungal (B) Colony Forming Units (average \pm standard deviation; two specimens sampled per condition) per $\mathrm{cm}^{2}$ of adhesive, obtained by sampling the surface and the inside of specimens, depending on their moisture and composition conditions.

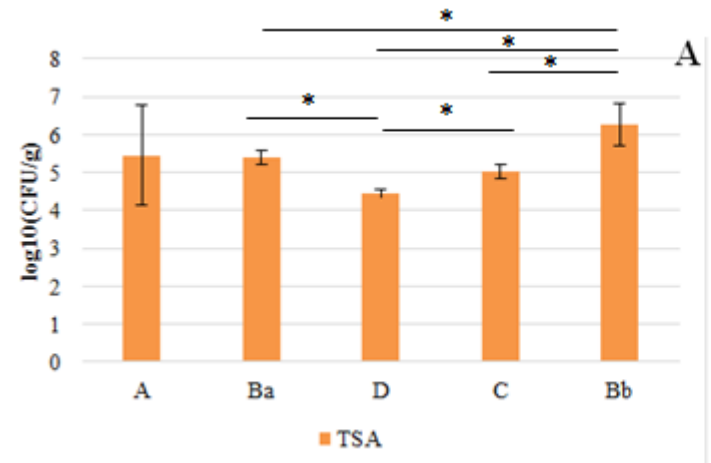

A

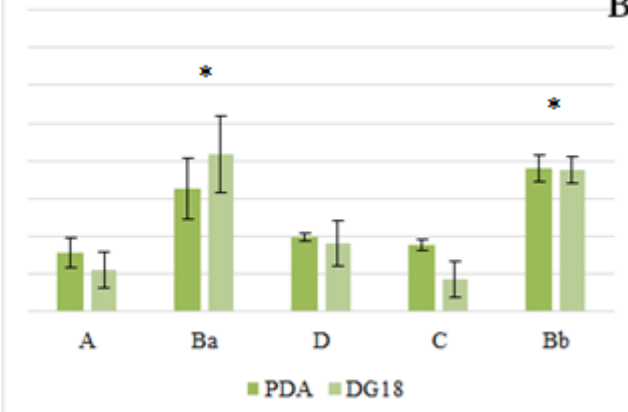

Figure 8. Bacterial $(A)$ and fungal $(B)$ Colony Forming Units (average \pm standard deviation; $n=3$ ) obtained by sampling the surface of earthen materials in situ. Fungal numerations for both $\mathrm{Ba}$ and $\mathrm{Bb}$ were significantly different from those for sites $\mathrm{A}, \mathrm{D}$ and $\mathrm{C}$. 
Isolates obtained from in situ sampling were identified as described previously. For all the buildings, the bacterial genus most frequently found was Bacillus (Table 2). Different species were isolated according to the sites but Bacillus simplex was present at the 5 sites studied. Other genera detected on the raw materials (i.e. Micrococcus, Solibacillus, and Staphylococcus) were present on only 1 or 2 supports. The presence of Gram negative bacilli was observed on different sites, either as Pseudomonas sp. or unidentified isolates. The genus Streptomyces was also highlighted. For fungi, the two most common genera were Penicillium and Aspergillus (Table 3). Cladosporium was detected on sites A and $\mathrm{B}$, while various other genera, such as Alternaria, Cladophialophora, Exophiala, Mucor, Rhizopus, Rhodotorula, Ulocladium or Wallemia, were not detected at more than one site. Culture-based microbial profiles seemed to be quite specific for each support rather than revealing a flora common to all earthen building materials

Table 2. Occurrences (grey cells) of bacterial taxa isolated by culture from sites $A$ to $D$ as identified by MALDI-TOF mass spectrometry.

\begin{tabular}{|c|c|c|c|c|c|c|}
\hline & & \multicolumn{5}{|c|}{ Sampling site } \\
\hline \multicolumn{2}{|c|}{ Identified Taxa } & A & $\mathrm{Ba}$ & $\mathrm{D}$ & $\mathrm{C}$ & $\mathrm{Bb}$ \\
\hline \multirow[t]{13}{*}{ Bacillus } & atrophaeus & & & & & \\
\hline & cereus & & & & & \\
\hline & indicus & & & & & \\
\hline & licheniformis & & & & & \\
\hline & mojavensis & & & & & \\
\hline & megaterium & & & & & \\
\hline & muralis & & & & & \\
\hline & mycoides & & & & & \\
\hline & niacini & & & & & \\
\hline & pseudomycoides & & & & & \\
\hline & pumilus & & & & & \\
\hline & simplex & & & & & \\
\hline & subtilis & & & & & \\
\hline Micrococcus & luteus & & & & & \\
\hline \multirow[t]{2}{*}{ Pseudomonas } & luteola & & & & & \\
\hline & stutzeri & & & & & \\
\hline Solibacillus & silvestris & & & & & \\
\hline Staphylococcus & haemolyticus & & & & & \\
\hline Streptomyces & griseus & & & & & \\
\hline
\end{tabular}

Table 3. Occurrences (grey cells) of fungal taxa isolated by culture from sites $A$ to $D$ as identified by macro and micro morphotype.

\begin{tabular}{|c|c|c|c|c|c|c|}
\hline \multirow{2}{*}{\multicolumn{2}{|c|}{ Identified Taxa }} & \multicolumn{5}{|c|}{ Sampling site } \\
\hline & & A & $\mathrm{Ba}$ & $\mathrm{D}$ & $\mathrm{C}$ & $\mathrm{Bb}$ \\
\hline Alternaria sp. & sp. & & & & & \\
\hline Aspergillus sp. & sp. & & & & & \\
\hline \multicolumn{7}{|c|}{ Cladophialophora sp. } \\
\hline \multicolumn{7}{|c|}{ Cladosporium sp. sp. } \\
\hline Exophiala sp. & sp. & & & & & \\
\hline Mucor $\mathrm{sp}$. & sp. & & & & & \\
\hline Penicillium sp. & sp. & & & & & \\
\hline Rhizopus sp. & sp. & & & & & \\
\hline Rhodotorula & mucilaginosa & & & & & \\
\hline Ulocladium sp. & sp. & & & & & \\
\hline Wallemia sp. & sp. & & & & & \\
\hline
\end{tabular}

\section{Discussion}

The characterization of the susceptibility of building materials to fungal growth addresses an important need in the construction sector, where it is important to have sufficient insight into their possible use and the ways to limit occurrences of mold. The aim of the current study was to quantify the microflora initially present in earthen materials and to characterize their ability to grow under favorable environmental conditions. Using the samples obtained before and after the drying step, it was possible to reveal the significant impact of the manufacturing process on the number of microorganisms present on the surface of and inside the test pieces. The $72 \mathrm{~h}$ heat treatment at $100{ }^{\circ} \mathrm{C}$ applied to specimens eliminated almost all bacteria on the surface, and brought the fungal population below the limit of quantification of the adhesive sampling technique. However, this heat treatment was not sufficient to eliminate the entire flora and did not affect all the microorganisms present, particularly in the heart of the specimen. Some authors have suggested that drying at temperatures above $80^{\circ} \mathrm{C}$ would sterilize the material [35]. Although the temperature was raised to $100^{\circ} \mathrm{C}$ in the core of the specimen here, some microorganisms survived. This is particularly relevant in relation to the dominance of genera able to sporulate among the isolates collected from raw materials [32] and from undried and dried specimens (Bacillus sp.) (data not shown). In addition, when these specimens were placed in very high humidity conditions, bacteria and fungi that had survived the heat treatment could develop again and proliferate up to the surface of the specimen. These results suggest that one origin of microorganisms growing on these supports may be related to the communities initially present in the soil and on the plant fibers used. However, even when a slight increase of CFU was noticed, no visible development was observed in the case of the ambient humidity condition, suggesting the need for high humidity to enable fungal growth on these materials, as for conventional building materials [10-12]. LaborelPréneron et al. studied the same type of material but under exposure to different temperatures $\left(20\right.$ and $30{ }^{\circ} \mathrm{C}$ ) and relative humidity levels $(75 \%, 84 \%$ and $93 \%)$, with water in vapor form [36]. No fungal growth was observed on these materials, regardless of the relative humidity of exposure. However, when liquid water was added to the materials (2.7 $\mu \mathrm{L} / \mathrm{cm}^{2}$ of material), proliferation was observed in the case of RH 93\%. It occurred after 6 weeks and only for the FWAS-S3\% composition. The impact of the liquid form of water on the ability of fungi to develop on building materials has also been highlighted for other materials $[16,37,38]$. Further works are needed to compare the susceptibility of earthen materials with that of conventional building materials, but the same environmental factors seem to be involved for these materials. It thus seems that the humidification of materials by liquid water (capillary rise, residual liquid water due to poor drying during the setting up of the material, etc.) is the most likely cause for microbial development on earthen materials.

Moreover, the addition of plant aggregates appeared to have an impact on the microorganisms in the material. First, the 
culture-based approaches on the specimens before the drying step revealed a higher fungal concentration in materials containing straw than in those with only raw earth. A study of raw materials alone had previously revealed a higher microbial concentration on straw fibers than on the FWAS used [32]. When the straw was incorporated into the building material, these plant fibers would add a significant amount of microorganisms to the specimen produced. When the FWAS-SO \% and FWAS-S3 \% specimens were placed in humid conditions, the kinetics of occurrence of the first mycelium was equivalent between the two formulations. However, the FWAS-S3\% specimens rapidly showed larger contaminated areas than the FWAS-SO\%. When samplings were performed after 3 months in humid conditions, the amount of bacteria per $\mathrm{cm}^{2}$ of adhesive was approximately $10^{8} \mathrm{CFU}$ for FWAS-S3 \%, which was $2 \log 10$ more than for FWAS-SO \%. Similarly, the surface of FWAS-SO \% had only one mycelium in a single area, the rest of the specimen having a fungal concentration around $10^{1} \mathrm{CFU} / \mathrm{cm}^{2}$ both on the surface and in the inside. In contrast, mold development on FWAS-S3 $\%$ specimens was significantly higher, with more than $10^{3}$ $\mathrm{CFU} / \mathrm{cm}^{2}$ over the entire specimen. Plant fibers could influence the growth of microorganisms in building materials in two ways:

- First, they constitute a source of carbon that can be used by certain organisms, thus promoting their growth. The same situation has been observed in the case of materials containing cellulose $[5,39,40]$;

- Another factor that can increase the development of microorganisms is the porosity of the material. In the case of FWAS-S0\% specimens, the soil was highly compressed, which resulted in a material with low roughness and few internal cavities. The addition of plant fibers traps air inside the specimen, which makes the material lighter and increases its thermal insulation performance [4]. However, increasing the material's porosity also promotes water absorption [5]. It also induces an increase in the surface area available for microbial development within and on the surface of the material.

The addition of plant fibers would, therefore, induce a higher susceptibility to microbial development under extreme humidity conditions, according to different mechanisms, but may not compromise the use of these materials for construction.

Samples from inside buildings constitute a first observation of the microbial density present on the surface of earthen walls. Bacterial density ranged from $1.1 \times 10^{3} \mathrm{CFU} / \mathrm{g}$ to $1.4 \times 10^{7} \mathrm{CFU} / \mathrm{g}$ across all samples, with an average of $1.2 \times 10^{5} \mathrm{CFU} / \mathrm{g}$ for all sites. In comparison, the concentration of bacteria was around $7.3 \times 10^{5} \mathrm{CFU} / \mathrm{g}$ for dust in offices [19] and $1.6 \times 10^{6}$ CFU/g for dust under beds [41], which is slightly higher but relatively close to the concentrations detected on the surfaces of the sampled earthen walls. However, samples from site $A$ revealed a high variability in the number of bacteria present depending on the height at which the wall was sampled, with a concentration 2 or even $3 \log 10$ higher at heights of $100 \mathrm{~cm}$ and $120 \mathrm{~cm}$ than on the rest of the wall. These variations could be related to the persistence of bacteria associated with previous uses of the building (i.e. presence of animals before renovation). In the case of other supports where the height varied $(\mathrm{Ba}, \mathrm{Bb}, \mathrm{D})$, this effect was not observed, suggesting a link with the history of the site.

Similar height-related variations were not observed for fungal flora. The fungal density on the sampled earthen supports ranged from $10^{1} \mathrm{CFU} / \mathrm{g}$ to $6.9 \times 10^{3} \mathrm{CFU} / \mathrm{g}$ on PDA media, with an average of $1.8 \times 10^{2} \mathrm{CFU} / \mathrm{g}$. The quantity of fungi measured in office dust, for example, varied from $8 \times 10^{3}$ to $4 \times 10^{5} \mathrm{CFU} / \mathrm{g}$ [42], which is a few log10 more than that detected on earthen materials. However, a significant difference $(p<0.05)$ could be observed between the areas $\mathrm{Ba}$ and $\mathrm{Bb}$ on the one hand (fungal concentration greater than $10^{3} \mathrm{CFU} / \mathrm{g}$ ) and the remaining sites on the other (fungal concentration between $10^{1}$ and $10^{2} \mathrm{CFU} / \mathrm{g}$ ). Site Ba was a wall made of adobe that had previously experienced a hydric accident (i.e. drain issue), leading to visible proliferation of fungal mycelia/spores on the surface. Among the fungal isolates obtained on this site, the Wallemia genus was strongly predominant. Since the genus Wallemia is able to grow at relatively low humidity [43], it is possible that this fungus was one of the first to grow when the wall began to be humidified. Although the problem was fixed (i.e. humidity returned to normal and fungi visually eliminated), quantification by culture approaches revealed the persistence of fungal flora which may have been those that grew during the humidification of the wall. The persistence of flora associated with water damage on building surfaces, despite partial or total remediation of the building, has been highlighted in several studies [44,45], and may explain this particular fungal abundance on this site. The second site with a large amount of microorganisms was the cob wall $\mathrm{Bb}$, and the presence of plant fibers may explain this observation. However, site $\mathrm{C}$ materials also contained vegetal aggregates, and its microbial concentration did not differ significantly from that at other sites. Since the majority of fungi in buildings come from the outside air $[27,46]$, the function of the $\mathrm{Bb}$ site room (i.e. storage of fruits and vegetables) could have contributed to the increase in the fungal colonization of this surface. In the light of the results obtained in situ, the impact of the room use and the history of the building seem to be critical. Similar results were observed in terms of microbial diversity with molecular approaches [28].

The microbial density of manufactured materials in the laboratory in the dry condition was several $\log 10$ lower than those of materials sampled in buildings, for both bacteria and fungi. The drying process was most likely different between manufactured specimens and in situ earthen materials, as the latter kind of material is usually dried at room or outdoor temperature for several days or weeks [33], while heat treatment is related to industrial production [35]. The buildings studied may have conserved a large part of their initial flora. However, this difference in drying conditions may not be the factor having the most impact on the microbial density on earthen materials in situ. As detected on manufactured specimens, both bacteria and fungi were able to grow slowly at room temperature and humidity, and the buildings sampled were constructed several years before the 
specimens were manufactured (they were only a few months old). Moreover, outdoor and indoor microbial flora were most likely deposited on the surface of materials over time $[27,46]$. However, even with a higher microbial density, naturally dried earthen materials used in buildings did not present visible microbial colonization under room environmental conditions. The overall results of this study suggest that heat treatment should be considered mainly to accelerate the drying step rather than for its microbial control effect. Larger sampling campaigns should be carried out to confirm these first observations.

In terms of identification, the microbial taxa detected in situ were partly similar to those obtained from manufactured earthen specimens. A large panel of Bacillus isolates was isolated at the different sites, with the presence of $B$. simplex on all surfaces. However, various other bacterial genera, including some potentially soil-derived genera such as Pseudomonas, Solibacillus and Streptomyces, were also present on in situ earthen materials. To a lesser extent, certain genera, particularly those associated with human cutaneous commensal flora (Micrococcus, Staphylococcus), were detected on only two sites ( $A$ and $C)$. Studies on the indoor environment (air and surface) by culture approaches have revealed that many isolates are associated with human presence $[19,47]$. In the case of the earthen walls sampled, the soil flora was predominant over the human commensal flora, despite the presence of these materials in habitats for several years. Concerning fungal flora, the genera Aspergillus and Penicillium were found at all the different sampling sites and in the earthen manufactured specimens. These two genera have been widely isolated in studies of the indoor environment by culture, whether in the air [21,48-50], in dust $[42,51]$ or on interior surfaces (wallpaper, plaster, office desk, etc.) $[20,21]$. The genus Cladosporium, widely distributed in outdoor air [49,52], was present in 3 of the 5 dwellings sampled. Finally, the other genera detected on a single site (Alternaria, Cladophialophora, Exophiala, Mucor, Rhizopus, Rhodotorula, Ulocladium, Wallemia) were also commonly detected in dwellings. As observed with molecular approaches across a wider sampling campaign on in situ earthen building materials [28], genera isolated by culture on these supports did not seem to differ from the type of flora detected in conventional habitats, while being partially sitedependent.

\section{Conclusion}

This study points out that one potential source of microorganisms in earthen materials could be the raw materials. Even if a manufacturing process involving heat treatment is applied, it will not prevent the subsequent proliferation of initial microflora persisting inside materials. The addition of plant fibers in the composition of the material led to an increase of the initial quantity of microorganisms along with a higher susceptibility to microbial development. The balance between insulation advantages and risks of fungal growth has to be considered carefully for the use of plant aggregates in earthen materials. Proliferation occurrences on the specimens, however, were only observed under extreme humidity conditions, and should therefore be considered in the perspective of the usual environmental conditions in buildings. Naturally dried materials used in building do not present visible proliferation unless affected by specific environmental conditions, even with the addition of plant fibers. Over time, the events encountered by the building and its specific use appear to be key factors in the microbial density and diversity on these surfaces. The fungal sensitivity results obtained should be extended to other formulations and/or other types of earthen materials (e.g. plaster), as well as compared to other types of conventional materials (e.g. gypsum). In addition, a wider sampling campaign on earthen buildings would be needed to confirm the observations obtained in this study and deepen the knowledge concerning these materials under in situ conditions.

\section{Acknowledgments}

The authors wish to thank the French National Research Agency (ANR) for funding project BIOTERRA - ANR - 13 - VBDU - 0005 Villes et Bâtiments Durables.

\section{References}

[1] F. Pacheco-Torgal, S. Jalali, Earth construction: Lessons from the past for future eco-efficient construction. Constr Build Mater (2012) 29: 512-519.

https://doi.org/10.1016/j.conbuildmat.2011.10.054

[2] M.J. González, J. García Navarro, Assessment of the decrease of $\mathrm{CO} 2$ emissions in the construction field through the selection of materials: Practical case study of three houses of low environmental impact. Build Environ (2006) 41 (7): 902-909. https://doi.org/10.1016/j.buildenv.2005.04.006

[3] C. Williams, S. Goodhew, R. Griffiths, L. Watson, The feasibility of earth block masonry for building sustainable walling in the United Kingdom. J Build Apprais (2010)6 (2): 99-108.

https://doi.org/10.1057/jba.2010.15

[4] A. Laborel-Préneron, J.E. Aubert, C. Magniont, C. Tribout, A. Bertron, Plant aggregates and fibers in earth construction materials: $A$ review. Constr Build Mater (2016) 111: 719-734. https://doi.org/10.1016/j.conbuildmat.2016.02.119

[5] C.P. Hoang, K.A. Kinney, R.L. Corsi, P.J. Szaniszlo, Resistance of green building materials to fungal growth. Int Biodeter Biodegr (2010) 64 (2): 104-113. https://doi.org/10.1016/j.ibiod.2009.11.001

[6] P. Höppe, I. Martinac, Indoor climate and air quality. Int J Biometeorol (1998) 42 (1): 1-7. https://doi.org/10.1007/s004840050075

[7] ASEF, Pollution de l'air intéreur de l'habitat, 2012.

[8] Conseil Supérieur d'Hygiène Publique de France, Contaminations fongiques en milieux intérieurs. Diagnostic, effets sur la santé respiratoire, conduites à tenir, 2006.

[9] B. Crook, N.C., Burton, Indoor moulds, Sick Building Syndrome and building related illness. Fungal Biol Rev (2010) 24 (3): 106-113. https://doi.org/10.1016/i.fbr.2010.05.001

[10] M.A. Andersson, M. Nikulin, U. Köljalg, M.C. Andersson, F. Rainey, K. Reijula, E.-L. Hintikka, M. Salkinoja-Salonen, Bacteria, molds, and toxins in water-damaged building materials. Appl Environ Microb (1997) 63 (2): 387-393.

[11] B. Andersen, J.C. Frisvad, I. Søndergaard, I.S. Rasmussen, L.S. Larsen, Associations between Fungal Species and Water-Damaged Building Materials. Appl Environ Microb (2011) 77 (12): 4180-4188. https://doi.org/10.1128/AEM.02513-10

[12] K.F. Nielsen, G. Holm, L.P. Uttrup, P.A. Nielsen, Mould growth on building materials under low water activities. Influence of humidity and temperature on fungal growth and secondary metabolism. Int Biodeter Biodegr (2004) 54 (4): 325-336. https://doi.org/10.1016/j.ibiod.2004.05.002

[13] [T. Verdier, M. Coutand, A. Bertron, C. Roques, A review of indoor microbial growth across building materials and sampling and analysis methods. Build Environ (2014) 80: 136-149. https://doi.org/10.1016/j.buildenv.2014.05.030 
[14] P. Johansson, A. Ekstrand-Tobin, T. Svensson, G. Bok, Laboratory study to determine the critical moisture level for mould growth on building materials. Int Biodeter Biodegr (2012) 73: 23-32. https://doi.org/10.1016/j.ibiod.2012.05.014

[15] C. An, N. Yamamoto, Fungal compositions and diversities on indoor surfaces with visible mold growths in residential buildings in the Seoul Capital Area of South Korea. Indoor Air (2016) 26 (5): 714-723. https://doi.org/10.1111/ina.12261

[16] S.C. Doll, Determination of limiting conditions for fungal growth in the built environment, Havard School of Public Health, 2002.

[17] C. Flament, Valorisation des fines de lavage de granulats: application à la construction en terre crue, Artois, 2013.

[18] A. Marcom, Construire en terre-paille. Terre vivante, Mens, 2011.

[19] L. Bouillard, O. Michel, M. Dramaix, M. Devleeschouwer, Bacterial contamination of indoor air, surfaces, and settled dust, and related dust endotoxin concentrations in healthy office buildings. Ann Agr Env Med (2005) 12 (2): 187-192.

[20] R. Santucci, O. Meunier, M. Ott, F. Herrmann, A. Freyd, F. de Blay, Contamination fongique des habitations: bilan de 10 années d'analyses. Revue Française d'Allergologie et d'Immunologie Clinique (2007) 47 (6): 402-408. https://doi.org/10.1016/j.allerg.2007.02.105

[21] H. Beguin, N. Nolard, Mould biodiversity in homes I. Air and surface analysis of 130 dwellings. Aerobiologia (1994) 10 (2-3): 157. https://doi.org/10.1007/BF02459231

[22] R.I. Adams, M. Miletto, J.W. Taylor, T.D. Bruns, The Diversity and Distribution of Fungi on Residential Surfaces. Plos One (2013) 8 (11), e78866. https://doi.org/10.1371/journal.pone.0078866

[23] R.R. Dunn, N.Fierer, J.B. Henley, J.W. Leff, H.L. Menninger, Home Life: Factors Structuring the Bacterial Diversity Found within and between Homes. Plos One (2013) 8 (5): e64133. https://doi.org/10.1371/journal.pone.0064133

[24] D. Hospodsky, J. Qian, W.W. Nazaroff, N. Yamamoto, K. Bibby, H. Rismani-Yazdi, J. Peccia, Human Occupancy as a Source of Indoor Airborne Bacteria. Plos One (2012) 7 (4): e34867. https://doi.org/10.1371/journal.pone.0034867

[25] S. Rocchi, B. Valot, G. Reboux, L. Millon, DNA metabarcoding to assess indoor fungal communities: Electrostatic dust collectors and Illumina sequencing. J Microbiol Meth (2017)139: 107-112. https://doi.org/10.1016/i.mimet.2017.05.014

[26] S. Lax, D.P. Smith, J. Hampton-Marcell, S.M. Owens, K.M. Handley, N.M. Scott, S. M. Gibbons, P. Larsen, B.D. Shogan, S. Weiss, J. L. Metcalf, L.K. Ursell, Y. Vazquez-Baeza, W.V. Treuren, N.A. Hasan, M. K. Gibson, R. Colwell, G. Dantas, R. Knight, J. A. Gilbert, Longitudinal analysis of microbial interaction between humans and the indoor environment. Science (2014) 345 (6200): 1048-1052. https://doi.org/10.1126/science.1254529

[27] R.I. Adams, M. Miletto, J.W. Taylor, T.D. Bruns, Dispersal in microbes: fungi in indoor air are dominated by outdoor air and show dispersal limitation at short distances. The ISME Journal (2013)7 (7): 1262-1273. https://doi.org/10.1038/ismej.2013.28

[28] A. Simons, A. Bertron, J.-E. Aubert, C. Roux, C. Roques, Characterization of microbiota associated to earthen materials. Appl Environ Microb (Submitted), 2019.

[29] A. Laborel-Préneron, Formulation and characterization of unfired clay bricks with plant aggregates, Génie Civil, Université Toulouse III - Paul Sabatier, 2017.

[30] A. Laborel-Preneron, J.-E. Aubert, C. Magniont, P. Maillard, C. Poirier, Effect of plant aggregates on the mechanical properties of earth bricks. J Mater Civil Eng (2017) 29 (12). https://doi.org/10.1061/(ASCE)MT.1943-5533.0002096

[31] A. Laborel-Preneron, C. Magniont, J.-E. Aubert, Hygrothermal properties of unfired earth bricks: effect of barley straw, hemp shiv and corn cob addition. Energy and Buildings (2018) 178: 265-278. https://doi.org/10.1016/j.enbuild.2018.08.021

[32] A. Simons, A. Laborel-Préneron, A. Bertron, J.E. Aubert, C. Magniont, C. Roux, C. Roques, Development of bio-based earth products for healthy and sustainable buildings: characterization of microbiological, mechanical and hygrothermal properties. Matériaux \& Techniques (2015) 103 (2): 206 https://doi.org/10.1051/mattech/2015011

[33] B. Pignal, Terre crue : techniques de construction et de restauration. Eyrolles, Paris, 2005.

[34] D. Kunwufine, Les propriétés des matériaux de construction en terre crue, 2011.

[35] U. Röhlen, C. Ziegert, Construire en terre crue : Construction Rénovation - Finitions. Le Moniteur, 2013.
[36] A. Laborel-Préneron, K. Ouédraogo, A. Simons, M. Labat, A. Bertron, C. Magniont,C. Roques, C. Roux, J.-E. Aubert, Laboratory test to assess sensitivity of bio-based earth materials to fungal growth. Build Environ (2018) 142: 11-21. https://doi.org/10.1016/j.buildenv.2018.06.003

[37] A.-L. Pasanen, P. Kalliokoski, P. Pasanen, M. J. Jantunen, A. Nevalainen, Laboratory studies on the relationship between fungal growth and atmospheric temperature and humidity. Environ Int (1991) 17 (4): 225-228. https://doi.org/10.1016/0160-4120(91)90006-C

[38] A.-L. Pasanen, H. Heinonen-Tanski, P. Kalliokoski, M.J. Jantunen, Fungal microcolonies on indoor surfaces - an explanation for the base-level fungal spore counts in indoor air. Atmos Environ B-Urb (1992) 26 (1), 117-120. https://doi.org/10.1016/0957-1272(92)90043-R

[39] H.-L. Huang, C.-C. Lin, K. Hsu, Comparison of resistance improvement to fungal growth on green and conventional building materials by nano-metal impregnation. Build Environ (2015) 93 (Part 2): 119-127. https://doi.org/10.1016/j.buildenv.2015.06.016

[40] J. Mensah-Attipoe, T. Reponen, A. Salmela, A.-M. Veijalainen, P. Pasanen, Susceptibility of green and conventional building materials to microbial growth. Indoor Air (2015) 25 (3): 273-284. https://doi.org/10.1111/ina.12140

[41] B. Horak, J. Dutkiewicz, K. Solarz, Microflora and Acarofauna of Bed Dust from Homes in Upper Silesia, Poland. Ann Allerg Asthma Im (1996) 76 (1): 41-50 https://doi.org/10.1016/S1081-1206(10)63405-9

[42] M. Pitkäranta, T. Meklin, A. Hyvärinen, L. Paulin, P. Auvinen, A Nevalainen, H. Rintala, Analysis of Fungal Flora in Indoor Dust by Ribosomal DNA Sequence Analysis, Quantitative PCR, and Culture. Appl Environ Microb (2008) 74 (1): 233-244. https://doi.org/10.1128/AEM.00692-07

[43] P. Zalar, G.S. de Hoog, H.-J. Schroers, J.M. Frank, N. GundeCimerman, Taxonomy and phylogeny of the xerophilic genus Wallemia (Wallemiomycetes and Wallemiales, cl. et ord. nov.). Antonie van Leeuwenhoek (2005) 87 (4): 311-328. https://doi.org/10.1007/s10482-004-6783-x

[44] J.B. Emerson, P.B. Keady, T.E. Brewer, N. Clements, E.E. Morgan, J. Awerbuch,S. L. Miller, N. Fierer, Impacts of Flood Damage on Airborne Bacteria and Fungi in Homes after the 2013 Colorado Front Range Flood. Environ Sci Technol (2015) 49 (5): 2675-2684. https://doi.org/10.1021/es503845j

[45] M. Pitkäranta, T. Meklin, A. Hyvärinen, A. Nevalainen, L. Paulin, P. Auvinen, U. Lignell, H. Rintala, Molecular profiling of fungal communities in moisture damaged buildings before and after remediation - a comparison of culture-dependent and cultureindependent methods. BMC Microbiol (2011)11: 235. https://doi.org/10.1186/1471-2180-11-235

[46] A.S.Amend, K.A. Seifert, R. Samson, T.D. Bruns, Indoor fungal composition is geographically patterned and more diverse in temperate zones than in the tropics. Proceedings of the National Academy of Sciences (2010) 107 (31): 13748-13753. https://doi.org/10.1073/pnas.1000454107

[47] J.S. Pastuszka, U. Kyaw Tha Paw, D.O. Lis, A. Wlazło, K. Ulfig, Bacterial and fungal aerosol in indoor environment in Upper Silesia, Poland. Atmos Environ (2000) 34 (22): 3833-3842. https://doi.org/10.1016/S1352-2310(99)00527-0

[48] A. Hyvärinen, M. Vahteristo, T. Meklin, M. Jantunen, A. Nevalainen, D. Moschandreas, Temporal and Spatial Variation of Fungal Concentrations in Indoor Air. Aerosol Sci Tech (2001) 35 (2): 688695. https://doi.org/10.1080/02786820117763

[49] B.G. Shelton, K.H. Kirkland, W.D. Flanders, G.K. Morris, Profiles of Airborne Fungi in Buildings and Outdoor Environments in the United States. Appl Environ Microb (2002) 68 (4): 1743-1753. https://doi.org/10.1128/AEM.68.4.1743-1753.2002

[50] C. Dassonville, C. Demattei, B. Detaint, S. Barral, V. Bex-Capelle, I. Momas, Assessment and predictors determination of indoor airborne fungal concentrations in Paris newborn babies' homes. Environ Res (2008) 108 (1): 80-85. https://doi.org/10.1128/AEM.68.4.1743-1753.2002

[51] H.J. Chao, D.K. Milton, J. Schwartz, H.A. Burge, Dustborne fungi in large office buildings. Mycopathologia (2002) 154 (2): 93-106. https://doi.org/10.1023/A:1015592224368

[52] A. Barberán, J. Ladau, J.W. Leff, K.S. Pollard, H.L. Menninger, R.R. Dunn, N. Fierer, Continental-scale distributions of dust-associated bacteria and fungi. Proc Nat Acad Sci (2015) 112 (18): 5756-5761. https://doi.org/10.1073/pnas.1420815112 